\title{
USING SOCIAL MEDIA TO IDENTIFY THE SOCIAL CAPITAL IN THE ROMANIAN DISCOURSES ON THE USE OF ENERGY FROM RENEWABLE SOURCES
}

\author{
Andra Alina BĂLAN* \\ Faculty of Geography, Babeș-Bolyai University, Cluj-Napoca, ROMANIA \\ andraopreaalina@gmail.com
}

\section{Oana-Ramona ILOVAN}

Faculty of Geography, Babeș-Bolyai University, Cluj-Napoca, ROMANIA oana.ilovan@ubbcluj.ro, ilovanoana@yahoo.com

\section{Cosmina-Daniela URSU \\ Faculty of Geography, Babeș-Bolyai University, Cluj-Napoca, ROMANIA cosmina.d.ursu@gmail.com}

\section{Cristina-Georgiana VOICU}

Titu Maiorescu Secondary School, Iași; Romanian Geographical Society, Iași branch, ROMANIA voicucristina2004@yahoo.fr

DOI: http://doi.org/10.23740/TID220195

*Authors contributed equally to this paper.

\section{ABSTRACT}

The present exploratory study aims to assess if there is any social capital supporting practices regarding the use of energy from renewable sources in Romania. For an effective investigation of the social capital and of the citizens' cohesion in perceptions and attitudes and their trust in public institutions at the community level the method used was the discourse analysis framed by a case study. The research material consisted of official documents on renewable energy in the European Union and Romania and of Romanians' opinions on social media (Facebook, YouTube, newspaper articles, blogs, etc.) concerning this topic. As results show, the presence of social capital can be identified from different perspectives within websites, considering both readers' and viewers' comments on the topic of renewable energy. By analysing the discourses, a major conclusion can be drawn: social capital can be either an obstacle or opportunity in formulating renewable energy policies and in implementing practices in Romania. On the one hand, the setbacks could be poor information (strictly profit oriented, unsustainable) and the population's mistrust of state mechanisms, which lead to community splitting, low proactivity and limiting innovation. On the other hand, sharing successful stories and encouraging civic spirit on social websites are manifestations of social capital resulting in an increase in the proactive level of the civil society.

Keywords: exploratory study, discourse analysis, institutions, civil society, sustainable development

Cite this article as: Bălan, A.A., llovan, O.-R., Ursu, C.-D. \& Voicu, C.-G. (2019). Using Social Media to Identify the Social Capital in the Romanian Discourses on the Use of Energy from Renewable Sources. Territorial Identity and Development, 4(2), 76-101. DOI: http:/l doi.org/10.23740/TID220195 


\section{NTRODUCTION AND THEORETICAL BACKGROUND}

From a theoretical standpoint, this study is based on three main concepts: renewable en ergy, social capital, and development discourses. These will be analysed critically and discussed below within the context of our research, in order to argue why the present research is necessary and point out what gaps it fills in.

\section{The approaches of the European Union and of Romania to renewable energy}

Worldwide, replacing the traditional energy sources with the renewable ones has gained popularity since the negative effects on the environment have been taken into consideration. Every continent has its own policies regarding this issue and tries to apply them in order to improve the quality of the environment. A global target is to reach $100 \%$ renewable energy until 2050 (Ram et al., 2019).

Therefore, the energy produced from renewable sources is a relevant topic, a developing sector that uses innovative technologies adapted to the principles of the sustainable development. Among several other measures, the sustainable development of the Europe an Union requires the promotion and development of renewable energy resources (CEMAT, 2000). The use of these resources supports adaptation to climatic changes, actually lowering the negative impact upon the environment while enabling innovative urban and rural planning. Using renewable energy is also part of the architecture of the sustainable landscape. All this entails educating the population to reduce the ecological footprint by decreasing energy consumption and air pollution. This is vital when aiming at a decentralized renewable energetic system. Today, the research focus is on increasing the efficiency of technologies that use renewable energy sources (EERA, 2019). However, during the implementation process, the public's response to the use of renewable energy is decisive, too.

The European Union has been promoted as a green actor in a competitive and environmentalfriendly sustainable economic model (Lequeux-Dincă \& Dincă, 2017; The European Commission, Directorate-General for Research and Innovation, 2018). According to a report released by Eurostat in 2018 (The European Commission, 2018), since 2004, the share of energy from renewable sources in the European Union almost doubled until 2014 (it has increased from $8.5 \%$ to $16 \%$ in 2014), the target to be reached by 2020 being $20 \%$ according to Directive 2009/28/EC (The European Parliament and the Council of the European Union, 2009). Given the fact that it is almost the end of 2019, a new target of $27 \%$ was proposed to be reached by 2030. Many EU states such as Sweden, Croatia, Estonia, Lithuania, and Bulgaria have set a national goal and have already exceeded it. Romania is amongst them, by reaching its target in 2014. This achievement would not have been possible without the strong involvement of the local communities, which have a decisive role in embracing the European legislation about renewable energy, given the fact that most of the projects are deployed in rural areas (OECD, 2012, quoted in Cebotari \& Benedek, 2017). In accordance with the European Union directives, Romania is growingly investing in renewable sources energy projects and is continuously developing the methodological basis for monitoring the me diumand long-term results.

Renewable energies enjoy an increasing attractiveness among the states of the European Union, with the share of renewable energy in gross final consumption increasing from $8.5 \%$ in 2004 to $17 \%$ in 2016 (Diaz Alonso, 2018). This increase was due to the setting of mandatory growth targets of the share of renewable energy stipulated in Directive 2009/28 / EC (The 
European Parliament and the Council of the European Union, 2009). Although the Union's 2020 targets have already been achieved (Figure 1), there are some member countries that have national level difficulties in reaching the present values in the case of the global share of renewable energy in gross final consumption and the specific share of renewable energy in transport (Figure 2). In order to facilitate the weights attainment established at the European Union level, our country formulated the Energy Strategy of Romania 2019-2030, with the Perspective of the Year 2050 (Ministerul Energiei, 2018) as the guiding document for investments in energy projects and methodological basis in order to quantify and monitor the results on the short, medium and long term.

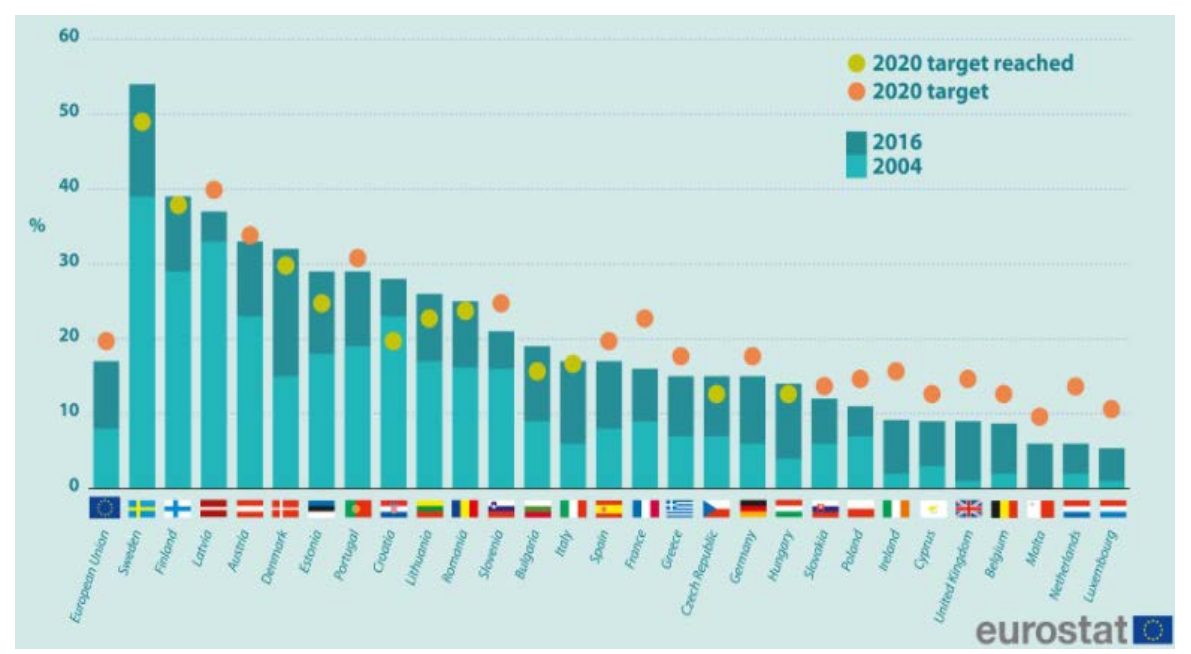

Figure 1: The percentage value of energy from renewable sources at EU level, 2004-2016 Source: The European Commission, 2018, fig. no. 1

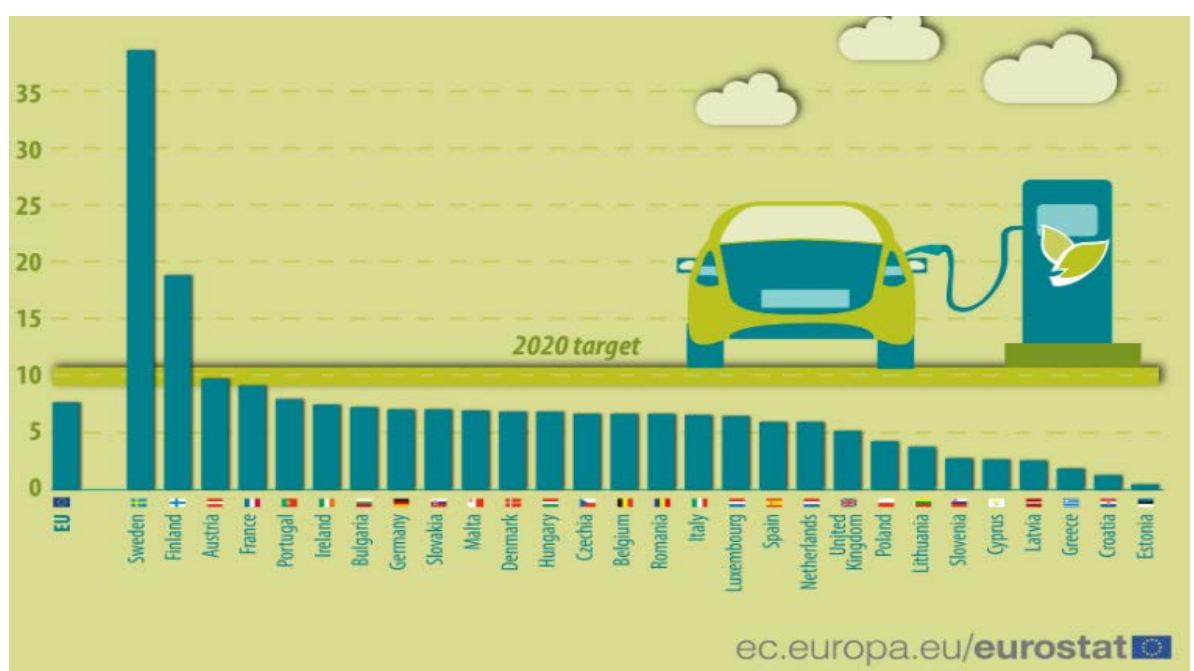

Figure 2: The share of the renewable energy use in transport, at EU level in 2017 
At the European level, the premises of the Energy Union become increasingly visible. Since 2000, the European Commission has associated the energy security of the European Union with ensuring the favourable environment for unhindered access to energy, but also with obtaining it at the most affordable prices, following the principles of sustainable development (Diaz Alonso, 2018; Šturc, 2016; The European Parliament and the Council of the European Union, 2009, 2018). Romania follows the European trajectory, through the formulated strategy, aiming at increasing the share of green energy production and channelling important financial resources in the modernization of the energy system (Ministerul Energiei, 2017, 2018; Parlamentul României, Camera Deputaţilor, 2010).

\section{Relevance of social capital for development}

When it comes to society's development, the social capital is a highly debated concept. After 1990, the economic development was linked to the social dimension and the relevance of social capital began to stand out (Bhandari \& Yasunobu, 2009). Putnam (1995, quoted in Wollebaek \& Per Selle, 2002, p. 33) argues for considering the social capital as a resource which can be used in order "to pursue shared objectives". Other scholars consider social capital "as a 'tool' in facilitating community activities" and the strength of it in a community is shown by the common goals achieved as a result of the cooperation between individuals, organizations, and community institutions (Tirmizi, 2005, p. 8). By facilitating the coordinated actions at the level of the organizational activity, the social capital contributes to improving community efficiency. This statement represents one hypothesis for which the pre sent study plans to provide preliminary data.

Although a prevailing sociological concept, the social capital was soon integrated into the economic activities as it represents a source of value and a relevant theory that contributes to performance within the management sector (Müller, 2014). Development economists analyse how a developing state can improve infrastructure, human capital, or legal environment within enterprises. Development involves not only increasing the income percapita, but it also means improving the quality of life, to which the cultural values that serve both as means and development goals are added. As such, economic phenomena can be explained by analysing both economic and social factors (Bhandari \& Yasunobu, 2009).

In the broadest sense, social capital refers to social relations among individuals that generate productive results. The existing studies both in the international and Romanian literature review demonstrate the interest, the wide application, the concept depth, as well as its political, economic, and social influences (Havadi-Nagy et al., 2017). Social capital is important for the modern economies, ensuring their efficient functioning and a stable democracy, being a solid foundation for the cooperation among different sectors and authorities. The fundamental dimensions of social capital result in ensuring the welfare of the society, interpersonal trust, and citizens' perception of governmental and political institutions' involvement (Arnstein, 1969; Fukuyama, 2010). Social capital is also relevant in gaining a certain education level, in the field of public health, community governance and a key element in production. The economic performance at national and regional levels is influenced by social capital (Claridge, 2004).

Being a complex concept, the social capital also defines a network of associations, activities or relationships that gather people in a community by certain norms, psychological capacities and particularly by trust. These aspects are essential for the civil society and efficient for future collective actions and goods (Müller, 2014). 
Robert Putnam popularized the concept of the social capital through his research on civic involvement in Italy (Putnam, 1993). Thus, he defines the social capital as the factor that refers to the characteristics of the organization - trust, norms and networks - to improve efficiency by enabling coordinated actions.

In his research, Putnam $(1993,2002)$ establishes a set of civic indicators. One of the key indicators is the trust in people and institutions. The level of trust within a community is caused by the likelihood of cooperation. A second indicator for the social capital is the norms of reciprocity. The individual trust becomes social trust by rules of reciprocity. These norms of reciprocity are another indicator of the social capital. According to this approach, the social trust in the modern complex comes from two sources: the rules of reciprocity and the networks of civic involvement. The third indicator of the social capital is networks. Civic involvement networks are essential forms of the social capital and the denser they are, the more citizens will cooperate for the common benefit. These networks can take the form of either neighbourhood associations, sports clubs, table games and anything that involves intense interactions on a horizontal line.

The distinctive signs of the civil community are mutual trust, social cooperation and a highly developed civic sense of duty. These three forms of social capital are called by Hirschman "moral resources" because, as they are delivered, they develop rather than decline through use and depreciate if not used (Hirschman, 1984). The social networks facilitate the transition and spread of the mutual trust.

In the modern economy, the social capital is seen like a binder that facilitates the unification of individuals in proactive civil societies, dominated by the feeling of belonging and trust (Bun dă, 2005/2006). We can deduce a direct relation between the social capital and the economic development, the first contributing directly to the facilitation of communication and to the direct access of the members of a company to the ones controlling other resources. The access to information is the first step towards evolution and development, social cohesion being vital for establishing the social climate within a community. The cohesion is strengthened by rich bonding and bridging social capital networks and contributes to increasing tolerance and avoiding social conflicts (Voicu, 2008).

According to P. Bourdieu, the social capital is not an antidote to the primacy of the economic principles in the human interactions, but an extension of these principles to non-monetary forms of interaction and exchange. In Bourdieu's view, the social capital is a resource based on group membership (Martikke, 2017). Another, more extensive conceptualization was developed by Bain and Hicks (1998, quoted in Claridge, 2004); it refers to the context in which organizations operate and includes a macro and micro level. The first refers to the institutional context, and the latter refers to the contribution of the organizations at the horizontal level and social networks in achieving development (Figure 3).

In recent years, we can see an increase of the interest for the importance of the social capital and social economy in Romania (Drăgan \& Popa, 2017; Havadi-Nagy et al., 2017), also as a result of the direct interest of the European Union in this field (Neguț, 2013). However, studies show that the communist heritage of Romania is a burden for present efforts to ensure the use of social capital as a resource for development (Haruţa \& Radu, 2010; Havadi-Nagy et al., 2017; Nistor, Tîrhaş \& lluţ, 2011; Soaita \& Wind, 2020).

In addition, Romania had not reached the required path yet concerning renewable energy in 2017. Thus, we can notice that something is missing in Romania, certainly not the potential. From the climatic point of view and the landforms configuration, Romania is characterized by 
diversity, any sub-branch of green energy having the possibility to develop (i.e. solar, wind, marine, hydropower, geothermal and bioenergy-Cristea et al., 2018).

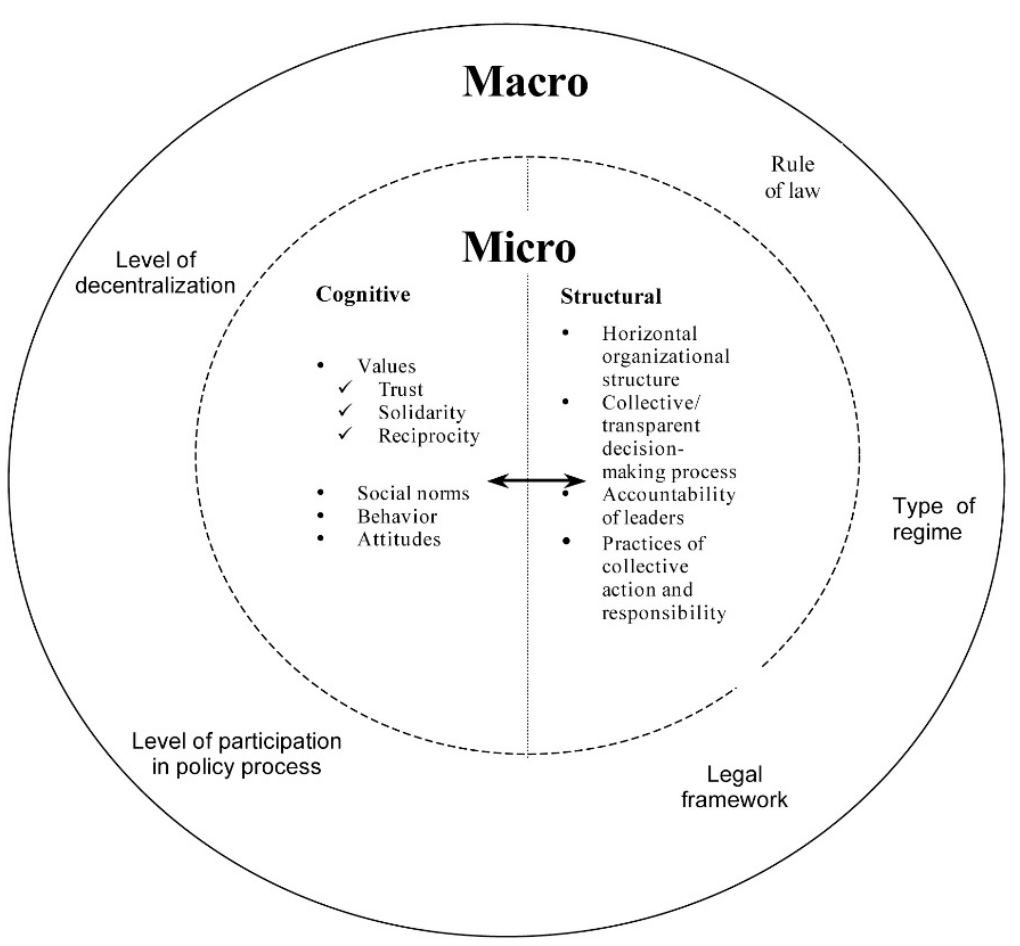

Figure 3: Social capital: Levels and types. A conceptual framework

Source: Claridge, 2004, p. 41, adapted from Bain and Hicks, 1998

Therefore, we can deduce that the limited weight could be determined by the inhabitants' awareness highly influenced by the social capital. Not only the mistrust in the public institutions, the low level of proactivity and entrepreneurial spirit, the lack of information flow, dysfunctional social relations, the low level of bridging and bonding social capital, but also the political and economic instability lead to the reluctance of the Romanian civil society towards involvement in large projects, as we will see in the presented case study.

\section{Discourses on sustainable development}

Research on this topic developed over the past decades and showed how discourses influence citizens' and public authorities' decisions. Using just a few examples to illustrate this point, one such research is that of Boas and Rothe (2016) who analyse the shift in discourse of climate changes from one being focused on the conflict to the present one, which embraces ideas about resilience. The authors show how the climate discourse evolved along the time, using statements of different organizations, policy makers and interviews with climate experts and officials. Every discourse emphasizes a certain point of view about climate change which is demonstrated to have changed and readjusted until present. Petersen (2007) focuses on the UN summits on sustainable development, which took place in Rio de Janeiro and Johannesburg, and uses television news stories to analyse the changes in environmental 
discourses. For each media text, a set of questions was applied to follow the changes that had occurred in discourses along the years.

A study conducted by Ferguson (2015) examines the discourses of several international organizations about the green growth. The author discusses the image created by each organization about growth and interprets the expressions used in descriptions, sketching a certain tendency of representing the green growth. A typology of the green economy discourse is developed: "weak green economy, transformational green economy, and strong green economy" (Ferguson, 2015, p. 27). In a similar study by Bär, Jacob \& Werland (2011), these researchers use discourse analysis to compare the perspectives of certain actors about the green economy. The authors say that this method "allows to systematically classify and structure positions on a specific issue that are held by stakeholders" (Bär, Jacob \& Werland, 2011, p. 6).

Considering these recent research interests in renewable energy, social capital and development discourses, our study will approach discourses on the use of renewable energy in Romania and will use the method of discourse analysis, which will be presented in detail in the methodology section below.

The purpose of this exploratory study is to assess if there is any social capital supporting practices regarding the use of energy from renewable sources in Romania. This research is necessary as it uncovers Romanians' perceptions on the use of renewable energy and their attitudes toward it. Such an exploratory study will pave the way for those who want to analyse to what extent the social capital influences the Romanians on the practices regarding the use of renewable energies. What it brings new to the field is the qualitative approach. We used official documents on renewable energy in the European Union and Romania, as well as social media as sources for our research material and then we used discourse analysis to analyse these sources, which, to our knowledge, has not been done before in Romania.

Discourse analysis is a method that can be applied successfully to analyse people's reactions (i.e. comments) on social media, the place where the topic was promoted the most. This is within the context in which researchers and public authorities in Romania consider it is imperative to shift towards eco-friendly energies, a shift that could be implemented more easily if the population were more informed and supported through national programmes to stimulate attractiveness to clean energies. The civil society's proactivity is directly proportional to the quality of the relationships and social networks horizontally established among community members and vertically between community members and authorities. Good governance achieved through the civil society's involvement leads to increased confidence in public institutions and stimulates entrepreneurship and leadership. Considering all this, our study fills a gap and results will further argue its necessity.

\section{MATERIAL AND METHOD}

In this section, we introduce some general description of the methods used for collecting and analysing data for the case study and then explain specifically how the data were selected and used, and how the methods were applied. 


\section{Data collection}

The data collection process was performed in two steps. First, we focused on documents rendering the discourse on renewable energy in official documents at the level of the European Union and of Romania. The second data set was represented by citizens' opinions about the renewable energy. We collected data by resorting to social media platforms as a natural form of expressive collectiveness. We searched on social media and online newspapers all opinions about the use policies and practices concerning the energy from renewable sources that is Romanians' perceptions and attitudes towards this use. Sources were not selected randomly, but we tried to cover all opinions as of March-April 2019. However, we applied two filters. Firstly, the citizens' comments were selected according to the research aim, namely, to show the existence or lack of the social capital and its possible influence upon implementing the policy and practices about renewable energy resources. Secondly, comments using offensive language were excluded.

Therefore, the data used for discourse analysis consisted of two sets according to the purpose of the study. The first one comprised the following several documents on policies and strategies, applied at the European and Romanian level: Directive (EU) 2018/2001 of the European Parliament and of the Council of 11 December 2018 on the Promotion of the Use of Energy from Renewable Sources (The European Parliament and the Council of the European Union, 2018), The Energy Strategy of Romania 2019-2030, with the Perspective of the Year 2050 (Ministerul Energiei [Ministry of Energy], 2018), and Law 220/2008 for Establishing the Promotion System for Energy Production from Renewable Energy Sources (Parlamentul României, Camera Deputaţilor [Parliament of Romania, Chamber of Representatives], 2010).

The second set of data for addressing the topic of our study was obtained by employing an integrated social media approach centred on social capital regarding the renewable energy within the Romanians' online discourse, by involving and prioritizing multiple variables as sources for social exploration (i.e. various statements, quotations from different social actors proving the current trend and its estimations, community's expectations, systematic observations of the specific trend from the perspective of social capital, notes on declarations, explanations, diverging discourses, general citizen reporting), which combined the visual (i.e. tables, grids, graphs, tracked figures, news, papers) with the verbal (i.e. civil society's comments / public opinion, online conversations on blogs and forums) and helped us in getting a deeper and clearer research picture of the Romanian inhabitants' perception of the policy's functionality about renewable energy resources and public authorities' involvement in implementing the related policy. We considered these analytical societal elements as multimethodical, participatory, reflexive, adaptable and focused on the Romanian citizens' lived experiences.

Although the existing theoretical frame on gathering data from social media networks is quite limited, according to our proposed constructivist approach, a comprehensive Romanian overview is achieved under this present study, in which those commenting on the topic are considered active agents and competent co-constructors of data and meaning makers, who may offer policy makers a glimpse into demand for renewable energy. As such, to reveal the general trends within our social media resources, the output of our qualitative data (comments, declarations, insights, etc.) were presented as concrete indicators of the current situation in Romania.

By reflecting on social media networks modelling (i.e. people-centred approach), based on both previous media content research on renewable energy (by which we bring into discussion 
a case selection of all social media interventions) and the role of public opinion (by monitoring Facebook, YouTube, the blogosphere as facilitators of public discourse) within the social system discourse, the advantage of using these data is that of providing a zoom in on the specific renewable energy sectors, by selecting the existing online communities in Romania. In addition, mining the social media for citizens' perceptions as well as practices and policies on renewable energy use is less expensive than surveys.

\section{Data analysis}

Data analysis was performed by using the method of discourse analysis. To identify/assess the existence of social capital and highlight the role that social capital plays in the practices regarding the use of renewable energy, firstly, the authorities' perspective is explained and reasoned, by using the discourse analysis. To retrieve the image constructed by the officials, quotes from various documents both from European and national contexts were added.

Secondly, the citizens' online comments were analysed from the perspective of social capital features. The online speech analysis considered the comments of the users on blogs and online forums that have the renewable energy as their topic. Their opinions were translated from Romanian into English after being collected from online resources like social networks (Facebook), comments to newspaper articles that aroused public reactions related to the topic of the study, etc. The persons' names are not revealed because of privacy issues, even if lots of them are not using their real names or full name. They are mentioned only as readers therefore gender was not considered. Each comment was interpreted in the context of social capital.

To sum up, firstly, the authorities view on renewable energy was analysed through the method of discourse analysis, then the citizens' opinions were commented on through the same method but adding the marks of social capital. Moreover, after discussing each opinion, a correlation with the authorities' view could be made to see to what extent there was a match between them.

The method for analysing the data used in this case study is the online discourse analysis through which we highlight how the civil society relates to the public authorities (to their discourse and practices), but also the level of the population's proactivity for the use of renewable energy and trust on public institutions. Discourse analysis could be achieved by using a qualitative or a quantitative approach. In our study, social capital features will be emphasized by analysing the language in both discourses (the official one and that of the civil society) and by explaining the metaphors used by readers regarding renewable energy. Thus, the qualitative approach is used, based on the interpretation of meaning, by hermeneutically interpreting discourse, where language and material elements of reality influence meaning production (Mattissek, 2010, p. 316, p. 318; Popa \& Dulamă, 2017), not a quantitative one.

Discourse analysis is a new approach in the scientific literature, which starts from the grammar of the text, continues with the linguistics of the text, and addresses the text as a set of phrase s related by coherence, cohesion, acceptability, and intentionality. The discourse can be vie wed as an individualized group of statements that corresponds to the principles of a discourse community, it can mean the communicative intent representing the author's intentions and what the recipient of the text understands and the discourse can refer to the negotiation of meaning and how reality is constructed. One definition for discourse is given by Hajer (1995, quoted in Peizerat, 1997, pp. 28-29): “a specific ensemble of ideas, concepts, and 
categorizations that are produced, reproduced, and transformed in a particular set of practices and through which meaning is given to physical and social realities."

Other scholars argue that "discourse shapes social reality, social identities, and social relations" (Fairclough, 1992, quoted in Coffey, 2016, p. 205). This means that discourse can be used intentionally, as a tool for representing realities in a certain way, controlled by various stakeholders. Dryzek (2005, quoted in Coffey, 2016) states that real social problems are seen only through "culturally constructed lens", meaning that the reality is shaped by cultural perspectives which are produced using metaphors. Concerning these, Fairclough (1992, p. 194, quoted in Coffey, 2016, p. 205) argues: "when we signify things through one metaphor rather than another, we are constructing our reality in one way rather than another". This shows that choosing metaphors must be correlated with the purpose of the discourse and every metaphor may result in a different kind of discourse.

Discourse analysis involves several steps: reading the text, examining the used language, and how the author's intentions are communicated through language to the recipients. This type of analysis has an interdisciplinary approach because it stands at the intersection of several fields, such as: Rhetoric, Linguistics, Philosophy, Sociology, and Psychology.

Sometimes, the speech is limited to being intended for speech, indicating a weighty conversation among participants, but, in general, the speech incorporates both spoken and written communication. While analysing the key concepts in language and linguistics, R. Trask (1999, quoted in Drid, 2010) states that a discourse is not limited to a speaker or writer, but may include oral or written exchanges produced by two or more persons. This approach thus becomes the cornerstone of the discourse analysis.

The researchers who conducted discourse analyses argued that the study of language could provide meaningful perspectives that were not always highlighted by other research methods. These records emerged by examining the ways in which language was used to achieve political and organizational targets, as well as by examining how the political documents were interpreted by the public auditing (Jacobs, 2006).

Coffey (2016) analyses the use of natural capital and economic metaphors in environmental policy discourse. One statement could also be applied for the present case study: "[...] such metaphors define the environment in particular ways, and that this is important because the way we think, write, and talk about the environment has implications for the way in which it is understood and governed" (Fairclough, 1992, quoted in Coffey, 2016, p. 204). As it can be generalized, the discourse on a subject influences its whole image and the public opinion as well. As it is shown in the article, using economic metaphors in describing environmental politics projects a certain perception about the environment. In the article, multiple discourses on the environment stemming from different policies are analysed. The number of specific economic metaphors shows the intention of presenting the environment as an asset (Coffey, 2016, p. 215). This demonstrates that every discourse has a specific purpose to distort the image of something according to a hidden aim. In quoting M. Foucault, Smith (1993) argues that relations of power lie behind every metaphor used in a discourse. Through discourse analysis, the true nature of language and its social meanings are deciphered; hence, language is "a social practice" (Peizerat, 1997, p. 30).

The discourse analysis requires that the person interprets every law, every statement as being a discourse, just a way of presenting facts induced by a certain person with a meaningful target. The authors doing such analysis should preserve their bird's-eye view objectiveness over the whole picture. The discourse analysis provides qualitative information which must be 
carefully processed. The one who analyses the content should be as little emotionally involved as possible and maintain a minimum level of subjectivity.

Since the $21^{\text {st }}$ century, the Internet has become the most useful tool for informing, promoting, and even expressing opinions on a certain topic of discussion. The Internet offers the possibility of anonymity, so specific platforms such as blogs or forums proved to be an unlimited data source for analysis of public opinion on several topics. From the beginning, it can be stated that since the development of the Information and Communication Technology (ICT), people find it easier to express their opinions on different contextual digital fields. Thus, by examining their reactions, we can observe some behaviours, values, and beliefs.

The advantages of the online discourse analysis stem from the fact that the individual's opinion is unfiltered as users do not have to reveal their identity. At the same time, individuals engage in online dialogues by commenting which can provide an overview on the topicality of the debated issue and of the civil society's general perception.

As for the disadvantages, even though our study kept the privacy of the online users by not disclosing their identity, this approach was limited by the possibility to involve more Romanian sceptics' or supporters' "narratives" as the online voice of renewable energy social landscape and to compare their visions with others' interpretation of the issue (a cross-cultural social capital on renewable energy), as it was extremely difficult to find other research studies on using social media as a complementary resource to support a critical view on this topic. Moreover, this context framed the social media users' interpretation on renewable energy which lead to affecting the actors' actions and thus influence whether renewables are integrated and the way they are integrated into the decentralised renewable energy systems architecture. A similar approach was used in a study on renewable energy in the U.K. as "discourse on renewable energy in the UK has been assessed using quotes of actors in newspaperarticles" (Buunk, 2016, p. 7).

Besides the aforementioned, another disadvantage of using this online approach was given by the interpreters' degree of reliability since the online social capital is used as a strategy by social media networks in supporting participation for profit of the renewable energy companies while challenging their "growing capacities of new storage technologies" (Marusyk, 2019 , p. 6), this being facilitated by exploiting a variety of network hosts / platforms.

Ultimately, by hypothesizing the capacity of digital tools and audience access options, our insights were distilled around social capital within defined online communities that provided the qualitative data for undertaking the current study.

Summing up, the research is based on two perspectives and discourses that will be presented in the results and discussion section below. On the one hand, the official's discourses regarding renewable energy and, on the other hand, the citizens' online discourses, which tackle the inhabitants' confidence level concerning the public institutions as well as their proactivity and the way the social capital could influence their decisions besides the ones taken by the public institutions (but also of the stakeholders in the private sector).

\section{RESULTS AND DISCUSSION}

In this section, we explore the connection between social capital and the usage of renewable energy across Romania. Moreover, the matches and the contradictions between both the 
authorities' and the citizens' views were identified. We concisely present the observations related to social capital as assessed from the analysis of each reader's/viewer's comments. We also considered offering solutions for a better cooperation among various actors in order to implement renewable energy systems.

\section{Discourse on renewable energy in the official documents}

When it comes to renewable energy policies, every European and Romanian discourse tends to emphasize various opinions. Using discourse analysis, we can deduce what aspects are most influential on this topic. The authorities' view is then connected to the citizens' remarks which are analysed from two perspectives: the signs of social capital and the matching between the renewable energy discourse of the communities and that of the authorities. For a better correlation with the readers' comments, the quotes from three official documents were numbered from 1 to 9 .

The newest official document is Directive (EU) 2018/2001 of the European Parliament and of the Council of 11 December 2018 on the Promotion of the Use of Energy from Renewable Sources (The European Parliament and the Council of the European Union, 2018). Among the first paragraphs of the directive there is one that counts the benefits of renewable energy, such as affordable prices, social and health advantages, increasing the employment of remote regions:

(1) "The increased use of energy from renewable sources also has a fundamental part to play in promoting the security of energy supply, sustainable energy at affordable prices, technological development and innovation as well as technological and industrial leadership while providing environmental, social and health benefits as well as major opportunities for employment and regional development, especially in rural and isolated areas, in regions or territories with low population density or undergoing partial deindustrialisation." (Directive (EU) 2018/2001, The European Parliament and the Council of the European Union, 2018, p. 82)

The Energy Strategy of Romania 2019-2030, with the Perspective of the Year 2050 (Ministerul Energiei, 2018) is derived from the European policy and also emphasizes the benefit of affordable prices:

(2) "The development policies and the correct adjustment of the level social assistance in the field of energy, especially in the poor areas, will ensure real protection of vulnerable consumers." (translated from The Energy Strategy of Romania 2019-2030, Ministerul Energiei, 2018, p. 9)

On the contrary, the study of Cebotari and Benedek (2017) contradicts the fact that rural areas might benefit from Renewable Energy Projects (REP). As it is stated in a Romanian case study, these projects come from private initiatives and, often, the local authorities cannot use the produced energy. The impact on local budget is limited, there are a few jobs created and no other trace of regional infrastructure development. In the best scenario, REP did act like "catalysts" (Cebotari \& Benedek) for rural communities to develop their own projects because they saw the benefits and they wanted to exploit their local resources. This matches partially the European policy idea of "technological and industrial leadership".

The role of the state is defined clearly in the Energy Strategy of Romania 2019-2030 (Ministerul Energiei, 2018) and the emphasis is put on the word "moderator", which shows that the state is in charge of balancing the prices of energy:

(3) "[...] the state has the essential role of moderator and market regulator" (translated from The Energy Strategy of Romania 2019-2030, Ministerul Energiei, 2018, p. 9) 
Besides prices, the state is the one that decides the energy policies, manages the projects, and implements them:

(4) "The state is legislator, regulator and implementer of energy policies [...]." (translated from The Energy Strategy of Romania 2019-2030, Ministerul Energiei, 2018, p. 9)

The Energy Strategy of Romania 2019-2030 (Ministerul Energiei, 2018) considers the proximity to Natura 2000 sites as a problem for renewable energy power plants, but one solution is given and that is the delimitation of ten areas where the authorization process is simplified:

(5) "Regarding environmental protection, a limiting factor in the development of new wind farms is the proximity to Natura 2000 areas and the overlap with the migration routes of the birds" (translated from The Energy Strategy of Romania 2019-2030, Ministerul Energiei, 2018, p. 39).

(6) "By 2025, studies will be developed and will allow the establishment of at least ten development areas of the wind and photovoltaic power stations on the national territory, the delimitation and maximum capacity that can be installed being determined in each area. In these areas of development, simplified procedures will be established for authorization works, for system connection, as well as for their authorization after commissioning" (translated from The Energy Strategy of Romania 2019-2030, Ministerul Energiei, 2018, p. 39).

The Law 220/2008 for Establishing the System to Promote the Production of Energy from Renewable Resources (Parlamentul României, Camera Deputaţilor, 2010), modified by The Government Emergency Ordinance (OUG no. 24/2017), aims at encouraging the production of renewable energy. The first article emphasises the importance of using green energy based on several listed reasons:

(7) “a) attracting renewable energy resources into the national energy balance, necessary to increase security in energy supply and reduce imports of primary energy resources;

b) stimulating the sustainable development at local and regional level and creation of new jobs related to the processes of using renewable energy sources;

c) reducing environmental pollution by reducing the production of pollutant emissions and greenhouse gases." (translated from Law 220/2008, Parlamentul României, Camera Deputaţilor, 2010)

The only reason for listing the first three points is to observe their order. As we can see, job creation and the economic benefits are put above reducing pollution and greenhouse gases, which suggests the express economic usages of renewable energy. This idea is not only present in the Romanian discourses, but also in the European ones. The quote no. 1, from Directive EU 2018/2001 (The European Parliament and the Council of the European Union, 2018), reveals the fact that the EU tries to bring to a common denominator the technological development and the environmental care by using the linking word "while": "[...] technological and industrial leadership while providing environmental, social and health benefits [...]."

When it comes to the availability of renewable resources, as far as the wind power is concerned, the Energy Strategy of Romania 2019-2030 (Ministerul Energiei, 2018) confirms that:

(8) "The main cause for which the technical potential of about 10.23 TWh / year is currently used is that the effectiveness of the national energy system which cannot take over the sources of non-predictable discontinuous production is only of $60.7 \%$. For this reason, any eventual development capacity of the wind turbines must be carried out in parallel with other developments to provide balancing services within the system." (translated from The Energy Strategy of Romania 2019-2030, Ministerul Energiei, 2018, p. 22) 
The main problem is emphasized using the phrase "non-predictable discontinuous production". This is further explained for other renewable resources, too, and, as a solution, technological development is expected.

Through the $17^{\text {th }}$ section of Directive (EU) 2018/2001 (The European Parliament and the Council of the European Union, 2018), the role of small installations in local communities is accepted. The key phrase is "public acceptance", an objective which could be achieved by various financial and procedural facilities employed by the state:

(9) "Small-scale installations can be of great benefit to increase public acceptance and to ensure the rollout of renewable energy projects, in particular at local level. In order to ensure participation of such small-scale installations, specific conditions, including feed-in tariffs, might therefore still be necessary to ensure a positive cost-benefit ratio, in accordance with Union law relating to the electricity market. The definition of small-scale installations for the purposes of obtaining such support is important to provide legal certainty for investors. State aid rules contain definitions of small-scale installations." (17th section of Directive (EU) 2018/2001, The European Parliament and the Council of the European Union, 2018, p. 84).

\section{The civil society's discourse}

Following the analysis of online content, we noticed some dominant features of the civil society, traits that at one point can positively or negatively influence the renewable energy practices, which can inhibit or encourage national and community renewable energy initiatives.

One of the dominant features noted in the online content is the distrust in the state institutions. Corruption, political opportunism, financial interests or even bureaucracy are factors that generate distrust, inhibit the technological progress, and diminish the interest of civil society towards the renewable energy industry. On a Facebook group named Energy for the future (https://www.facebook.com/energiaviitorului/), which was created in October 2016, various news related to renewable energy are shared. In the statements below, the individual argues ironically that using other energy sources than the classic ones would diminish the taxes taken by the state:

"Do you want the state autonomous enterprises to die?" - reader (Source: https://www.facebook.com/energiaviitorului/posts/1616366208422771,October 2018)

Another post of the group Energy for the future is about the progress of China's solar energy. One comment suggests that competition is not wanted in Romania:

“... In Romania no competition is desired" - reader (Source: https://www.facebook.com/energiaviitorului/posts/1554311184628274, October 2018)

Even if many articles arouse negative reactions, there are some which manage to generate solutions to some problems. Still, there are some who blame the state institutions indirectly:

A: "Why not use this money for investments in increasing energy efficiency, distribution and residential, as well as alternative energy sources?"

B: "The truth is that nobody is doing anything for the interest of Romania." - reader (Source: https://www.facebook.com/energiaviitorului/posts/162265714446034, October 2018)

On a YouTube film about building a wind power plant in a Romanian city (Tulcea), some comments had a double meaning. On one hand, the viewer encourages the initiative, but then he or she blames the Government for pursuing only personal interests. As it can be remarked, 
the statement seemed to be linked to renewable resources, but, in the end, it proved to be an overall expression of distrust in state institutions:

"Do you see that it is possible? The Romanian government is not interested in wishing us well. They are all about personal interests, about the humankind's indebtedness to be easily manipulated." - viewer (Source: https://www.youtube.com/watch?v=LpDf4R_4Vwo, November 2018)

The online mass-media about renewable energy hosts also opinions shared by the readers. One of the articles in 2013 introduces the statement of a former official from an electricity power plant (Hidroelectrica) announcing that many projects of renewable energy would fail because there is a surplus on the market. One reader wishes the failure of the companies which increased the price of energy:

"I would be very happy if these companies collapsed. I would understand if something almost free is obtained ... if kwh cost drops. So, I am not interested in any of these wind turbines which make the price of energy to increase." - reader (Source: http://www.ziare.com/mediu/energieregenerabila/remus-borza-avertizeaza-sute-de-proiecte-din-energia-regenerabila-vor-esua-

125466, October 2018)

The reader's view contradicts the European Directive 2018/2001 (quote no. 1) (The European Parliament and the Council of the European Union, 2018) that claims affordable prices on renewable energy: the green energy is supposed to provide fair prices on energy. However, when there are also other factors involved (like market competition, financial interests), the renewable energy proves to do the contrary. Also, the problem raised by the reader shows that the state does not intervene as "moderator" (quote no. 3) of the energy market, as it is stated in the Energy Strategy of Romania 2019-2030 (Ministerul Energiei, 2018).

Another article is written by a group of NGOs and it shows how hard it is to get a construction permit for wind power plants. One reader shares his or her experience and he or she relates to the difficulties mentioned in the article, but also blames the corruption of state institutions:

"correct ... that's how it happened to me too ... I have never seen so much corruption in the world before even though I travelled everywhere ... the whole system is hand in hand ... politicians, judges, police, mayors, county council staff, etc. and so on ... you can't complain anywhere because they are they ..." - reader (Source: http://www.ziare.com/mediu/energieregenerabila/investitiile-in-energia-regenerabila-din-romania-se-fac-cu-taxa-pe-prietenie-

1034989\#comentarii, August 2010)

This remark is linked to the role of the state as the one who establishes the policies (quote no. 4) and it shows the fact that the state is the only authority managing the energy investments and can sometimes prevent independent citizens to develop their renewable energy projects.

In addition to distrust in public institutions, the inhabitants condemn the opposition of some NGOs regarding the implementation of certain energy production technologies. The population perceives the field of renewable energy as contradictory, as the renewable e nergy is associated mostly with advantages, yet the effects on biodiversity are somehow minimized. The contradictions in this field discourage potential private actors. NGOs can thus encourage the renewable energy practices and policies, but they can also become opposition actors. Here is one comment of a reader that exposes openly his point of view about the connection between NGOs and renewable energy:

"What renewable energies can develop further when NGOs land any investment attempt in this area? The wind turbines disturb the birds, the hydroelectric plants (the ones without the dam) would disturb the fish, and the solar parks shade the cockroaches. Under the pretext of 
environmental protection, a handful of NGOs are blocking everything, and nobody explains people that there can be no zero impact on nature. And, if we want energy, we must choose the path of renewables, which have minimal impact on the environment because first of all in the energy production process they have ZERO pollution." - reader (Source: https://www.facebook.com/energiaviitorului/posts/1563559287036797, October 2018)

The problem is also reported in the Energy Strategy of Romania 2019-2030 (quote no. 5) (Ministerul Energiei, 2018), but the given solution (quote no. 6) has not been put into practice yet. Moreover, the delimitation of only ten areas (Ministerul Energiei, 2018) will not help a regular citizen who wants to install a smaller power plant.

Another individual also emphasizes the overreaction of NGOs, but in the end, he or she admits the fact that financial benefits for using green energy overcome those related to reducing pollution:

"I do not want to believe that I give no dime on nature, the project of the future house also contains panels of all kinds and wind turbine, but the egg thing and the transit of the birds seemed to me a dissuasive fact for potential energy competitors and not an encouraging one for nature. As I said before, I also plan to invest in green energy, but I admit that it is for the economy firstly, and secondly for pollution." - reader (Source: https://forum.softpedia.com/topic/688941-investitii-verzi-pe-teritoriul-romaniei/ October 2018)

The statement is also linked to quote no. 6 , but it has a meaning for quote no. 7 as well. The reader embraces the view of Law 220/2008 (Parlamentul României, Camera Deputaţilor, 2010), which puts the economic purposes above the environmental ones. As we can deduce, the citizens have the same line of thought as the public authorities, at least regarding this matter.

Within the online material, we can distinguish citizens oriented to innovation, persons who are entrepreneurial and proactive. People who are proactive and open to implementing a renewable energy production project are informed, both from the point of view of the environmental benefits and from that of the opportunities on the market (national and European funding programs). Informing and transmitting information through social capital networks increases the level of the bonding social capital, facilitates cluster coagulation, and implicitly increases the level of proactivity of the civil society.

"Beautiful and useful and praiseworthy, except that ... besides the sun, rain and wind, our man has privatized some of the community assets as well, as also people live in nature. The facilities man has, the wind turbines, the water tank and the parabola cost a lot of money on the market, costs that cannot be covered by selling dried plums." - reader (Source: https://www.youtube.com/watch?v=f-e_g6b1GaA, October 2018)

This statement reveals another truth about the price of renewable energy: whereas the natural resources are free, the equipment for producing energy is very expensive. In this way, the affordable prices of energy debated in the European and national policies (quotes no. 1 and 2) are disputed.

\section{Other readers express their openness to innovation when it comes to renewable energy:}

"... unconventional clean energy comes into force ... coal will remain ... history" - reader (Source: https://www.facebook.com/energiaviitorului/posts/1546368625422530, October 2018)

There are some who link renewable energy with progress and research, but also take into account further challenges - how to feed the increasing global population:

"The world is in progress. Progress involves science, research, searching so that the lost energy is stored, or used in return, within an integrated network system. Countries that focus on searching, research, or science have the energy future as assured. The consumption of fossil 
fuels, whose deposits are markedly low, will be reduced. Not all the mysteries of nature have been discovered yet. After energy, the challenge is to feed the population, where genetics will triumph by modifying some now-wild plants." - reader (Source: http://www.ziare.com/economie/stiri-economice/lectia-germana-a-energiei-regenerabile983254\#comentarii, October 2018)

The online content also reflects negative opinions about the productivity of renewable energy projects. At the same time, the dissatisfaction generated by the Romanian system leads to scepticism and the formation of a public opinion, influenced by the political and economic instability in the Romanian space. It is also visible the orientation of the population strictly for profit, omitting the other benefits deriving from energy independence or reduced ecological footprint:

"With 8.000 euros I pay the electricity all my life to the distribution networks, for 10 households, if I consider the supplies that need to be changed periodically, such as batteries. Good deal!" reader (Source: https://www.youtube.com/watch?v=c5jtDZ-MFZc, October 2018)

Some readers are complaining about the documentation required for installing renewable devices and the low prices obtained for selling the green energy:

"Now after 4 years and 2 months since the publication of the article, it was found to be purely idealistic. I do not know why ANRE [Autoritatea Naţională de Reglementare în Domeniul Energiei - National Authority for Regulation in the Field of Energy] announced that everything would be simplified for domestic producers, but nothing has been simplified. It is very difficult to prepare and submit the entire required documentation. The price offered for sale is three times lower than the purchase price. There are very few domestic energy producers in Romania." - reader (Source: http://riscograma.ro/7532/cat-de-rentabila-este-mica-productie-de-energie-electrica/, October 2018)

This comment clearly demonstrates that the domestic producers are not encouraged to equip their homes with renewable energy systems, which leads to inhabitants' disinterest. This is the evidence that contradicts the $17^{\text {th }}$ section of Directive (EU) 2018/2001 (quote no. 9) (The European Parliament and the Council of the European Union, 2018) and shows that the measures taken by the state are not enough.

About the viability of renewable energy, not all readers are convinced by it. They think that manufacturing the components for wind power plants or solar panels will require the use of the already existing resources:

"In the current system, the alternative energy is not viable. Which material will they use in making the plastic, rubber, or other things needed by cars, other machines, or batteries? Everything is made of oil. What they will achieve will be the destruction of the economy so far." reader (Source: http://www.ziare.com/mediu/energie-regenerabila/investitiile-in-energiaregenerabila-din-romania-se-fac-cu-taxa-pe-prietenie-1034989\#comentarii, October 2018)

Other readers communicate different opinions about the feasibility of renewable technologies. On the one hand, the use of green energy is encouraged, but on the other, some consider that there are some drawbacks which can be surpassed by further innovative technological solutions. This statement also matches the authorities' view (quote no. 8), who are aware of the hindrance of using the renewable energy and assume the same solution as the reader:

"All good and beautiful, especially since it is a profitable business for many. Just that, for technical and commercial reasons, we can only rely on a limited proportion of wind energy, or solar energy, which has a pronounced variable character (they are not always available at the peak of consumption or are available at maximum power just when we have a lack of consumption). Until efficient energy storage technologies are available on an industrial scale, 

http://www.ziare.com/economie/stiri-economice/lectia-germana-a-energiei-regenerabile983254\#comentarii, October 2018)

\section{Some discussions on the social capital. Obstacle or opportunity for renewable energy practices} in Romania?

After the above presentation and discussion about the results of this research, we will pay attention to other findings from relevant literature on the topic, either at the international level or considering the case study of Romania and areas within this country. For instance, the existence of social capital can be a trigger to the development of rural areas in Romania which have renewable resources. The most important fact is for them to oversee implementing and using the projects, not to let other private actors to exploit resources (Cebotari, 2017). Another study suggests that rural areas should be involved in implementing renewable energy projects in order "to increase public acceptance and awareness of sustainable energy production and its commercial opportunities", which can contribute to a "more balanced rural development" (Benedek, Sebestyén \& Bartók, 2018, p. 529). In this way, we can confirm that social capital is a valuable resource which can enhance economic development (Bhandari \& Yasunobu, 2009).

Generally, previous studies at the Romanian regional and national level considered main economic indicators, trends and challenges in the renewable energy sector and mostly on quantitative approaches (Cristea et al., 2018; Cebotari \& Benedek; Cebotari, 2017), and evaluation methodology for renewable energy potential (Benedek, Sebestyén \& Bartók, 2018). Our study fills in a gap in the field, focusing on the role of intangible social resources (i.e. social capital) for development, using a qualitative approach through the discourse analysis method, while underlining the relevance of social media in providing research material and also in discussing hot topics of the Romanian society and, at the same time, raising citizens' awareness on the subject of promoting the use of energy from renewable sources.

As we have stated before, the social capital can be an obstacle or opportunity in formulating the renewable energy practices and policies. In Romania, its manifestation, with its two dimensions of bridging and bonding (Havadi-Nagy et al., 2017, p. 14), can enhance or prevent the development of the renewable energy sector. The field of renewable energy is a "new" field in Romania - the emergence of cooperatives, as citizen-based initiatives in this field (Huybrechts \& Mertens, 2014) could be a solution only if social capital is enhanced, as social capital is a highly contextualized specific variable (Claridge, 2004, p. 4).

Considering the results of the discourse analysis, it can be stated that the main obstacle to initiating and maintaining green energy practices and policies is the population's distrust in state mechanisms. Distrust divides the community and lowers its proactivity and the desire for the civil society's involvement, thus limiting innovation. The population's distrust in the state mechanisms is a trend in the countries that were part of the past Communist Bloc, democracy being cultivated only recently, the process of involving the population in the problems of the community being at an early stage. Thus, corruption, political tensions, economic instability, and bureaucracy inhibit the development of this branch of innovative energy. People's low level of confidence inhibits their entrepreneurial affirmation and decreases their desire to explore a topical area in the European space.

At the same time, considering the analysed online comments, it can be deduced that the financial dimension is paramount among the population, the sustainable growth of the initial projects or the orientation towards protecting the environment is not a concern. Poor 
information, lack of a vision with a long-time extension or even insufficient involvement of public information mechanisms lead to the lack of an integrated strategy for the renewable energy, many of the benefits being omitted.

However, in the online resources one can distinguish success stories or good practice examples of those passionate about the field. Some of the users of the online platforms prove openness to this innovative field, they want to become more informed, and they feel the need to share with others the new energy practices and policies. In this case, we can deduce that bonding social capital networks exist, but they are inhibited by the distrust in the institutions. Bridging social capital networks are the expression of the policies and practices regarding the renewable energy at community level. Foreign private actors may also develop bridging networks, but the Romanians prove to be sceptical because of recent past controversial events and processes (i.e. privatization of the industry since 1989).

We can conclude that although present, the social capital is predominantly non-functional within the Romanian civil society, due to the population's reluctance, generated by past experiences, present political and economic instability, and also by the distrust in the public institutions and their policies.

However, the encouraging interaction between society and technology shows that the process of informing the population is vital in order to cultivate their openness to new, innovative areas. Of course, education is the promoter of the innovation process, so it is crucial that the openness to the innovative process is cut off from school (Figure 4).

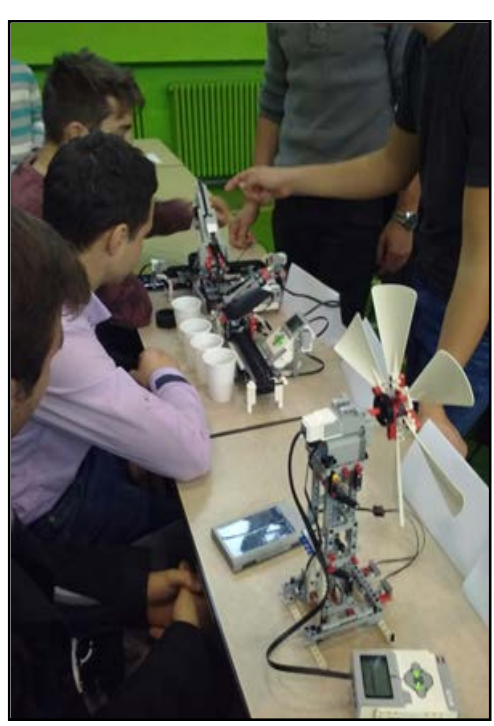

Innovation is a multidisciplinary concept widely publicized within the national and community practices and policies. The success of these practices and policies in the field of the renewable energy is conditioned by the existence of a specialized, passionate and open to new workforce, who can transmit the information through the bonding social capital networks. It is very important for bonding networks to be functional because civil society is much more open to local projects and successful stories. Thus, the focus on specialized education, sections with technical and energy profile, can improve the social capital level.

Figure 4: The students of Turda Technical College participate in a project competition with a Lego mini wind turbine

Source: Photograph by Daniela Alina Oprea, March 2017

Of course, population's information and education are desirable to be ensured throughout life, this being possible through workshops, clusters or through consultancy from public institutions. This would cultivate openness to the new and receptivity to the energies of the future, making the national policies more attractive and accessible to the population concerned.

The local energy consultancy agencies play an important role in promoting the renewable energy practices and policies, through their advisory role, but also of direct involvement in the implementation process. These agencies take the form of non-governmental organizations that locally support the renewable energy industry and energy efficiency. Some examples of 
such local organizations are: ABMEE (The Energy Management and Environmental Protection Agency Association Brașov), ALEA (Local Energy Agency Alba), AMES (The Agency for The Energy Management Sighișoara), OER (The Energy Cities in Romania) (Agenţia Locală a Energiei Alba, 2009, 2014; Agenţia pentru Dezvoltare Regională Centru, 2010). These agencies were born from European funding and provide various consulting services, monitoring and implementation of the renewable energy projects and practices. They are involved in international cooperation, representations participating in conferences and programmes of national and European importance. These organizations are set up as bridging social capital resources, which connect local communities with the internationally available information.

Either local, regional or national, the basis of the efficient functioning of a system is represented by the cohesion of the component elements, in this case of individuals as part of the civil society. To have an image on the cohesion of a society, it is important to consider the following variables: disparities, inequalities, social exclusion related to social relations, networks, social capital (Manole, 2012). The functionality of a social group is directly proportional to the cohesion among its members. To achieve a high level of cohesion, it is important that the group has well-established goals that contribute to the community development by reaching them. The objectives can be set both at the institutional level, through projects or development strategies, and at the civic level, through the representatives of the civil society, who have the possibility to expose the problems that the community faces.

At the same time, the local leadership, the proactivity and cultivation of the feeling of belonging, but also the success stories and examples of good practice at the local level, improve the relationships established at the social group level, forming more civically active communities, with an integrated vision and entrepreneurial spirit. The models of good practice must also be promoted through media which is currently among the main opinion-makers.

\section{CONCLUSIONS}

Finally, we sum up the observations derived from results, the limitations of this research and suggestions regarding future research.

Social capital is an important concept in the activity of leadership development and represents a set of features of social organization (i.e. networks, norms, and trust) that support coordination and cooperation for a common purpose and thus enable mutual benefit. The social capital plays a significant role in collective action, which is formed in turn or through collective activities, social interaction (social capital networks) and cooperation among actors. The impact of a social network results in more opportunities for the social capital formation and faster achievement of goals.

In the present study, the use of renewable energy was analysed from two different perspectives: one of the authorities and the other of the citizens. It is shown that the Romanian official view, as reflected in documents issued by public institutions, strongly embraces the European legislation by trying to accomplish the imposed targets when it comes to the use of renewable energy. Moreover, by employing the discourse analysis, some key aspects on which the authorities insist were emphasised. In the second part, the citizens' vie w about renewable energy was observed through their comments from social media. Both the presence of social capital and the correspondence with the authorities' view were analysed. The contradictions are linked with the prices of renewable energy (the authorities suggest 
lower prices, but the readers claim that the prices are high), the role of the state as a "moderator" (which is denied by the citizens) and the problems faced by domestic users to build their own energy source (which, according to the authorities, should be enabled). But besides contrary opinions, there were also matches in the two discourses (i.e. the official one and that of the citizens): the obstacles imposed by the proximity of protected areas, the economic purpose that is placed above the environmental one, the limitations in using renewable resources at large scale because of their inconsistent production and the need to develop innovative technologies in order to expand the use of green energy sources.

The online speech analysis provides details on the level of the social capital of the target community, its cohesion, and on the trust level in public institutions in Romania. The analysis of the online resources reflects the existence of social capital, despite the low level of population's confidence in the public institutions. However, precarious information makes it difficult to reach the national and community objectives in the field of green energy.

We included the observations made from an online perspective. The online discourse provided us more nuanced views on targeting the Romanian community response to easily determine the level of discussions about renewable energy sources. In addition, by citing social media, the scientific output placed an emphasis on people's acceptability of renewable energy general trends that helped us in identifying the Romanians' awareness of their trust level in public institutions.

Finally, we can conclude that the process of formation and consolidation of social capital is a sustained process, often with a long-time extension. The success of the implementation of the national and community practices and policies depends on population's perception of the field of implementation, access to information, formal or non-formal education in the field, development of the capacity for innovation, capacity that can be exercised through the proactivity and involvement of the civil society in the governance process. Therefore, as from the energetic point of view, Romania is currently in a transitional period, tending to maximize the share of renewable energy in both transport and the share of energy from the ren ewable sources, the implementation of the renewable energy projects and practices is also desirable to have a consultative perspective, involving the population in the local governance process and encouraging leadership actions to contribute to the innovative process.

The limitations of the research have multiple sources. Firstly, it is hard to decide which public documents are the most relevant for the study, even if all of them share the same large ide as. More documents could be selected to overcome such a limitation during future research. As for the present study, the authorities' point of view was expressed through three different sources (Directive (EU) 2018/2001 of the European Parliament and of the Council of 11 December 2018 on the Promotion of the Use of Energy from Renewable Sources (The European Parliament and the Council of the European Union, 2018), Energy Strategy of Romania 20192030, with the Perspective of the Year 2050 (Ministerul Energiei [Ministry of Energy], 2018), Law 220/2008 for Establishing the Promotion System for Energy Production from Renewable Energy Sources (Parlamentul României, Camera Deputaţilor [Parliament of Romania, Chamber of Representatives], 2010).

Secondly, given the various opinions taken from social media, it is difficult to cover all the aspects regarding one subject. For more objectivity, qualitative and quantitative techniques could be employed as part of discourse analysis. Another limitation could be even the translation of the opinions from the native language (Romanian) into English; because some 
words cannot be translated exactly, they could partly lose their meaning. This aspect is important to be mentioned especially when the discourse analysis method is concerned.

Beyond all the inconveniences and limitations encountered during our research, the findings provided us an opportunity to explore how the Romanian civil society has adapted to changing settings in the networked public sphere, and its role within a self-governing society. Specifically, a better understanding of participants' factual opinions allows a more critical future approach to be taken in using social media to spot the social capital in renewable energy online discourses from Romania. Following the study, we can conclude that the level of the social capital depends on the population' receptivity to governmental policies, and proactivity level, generating a high interest regarding the involvement in a future project. The bonding capital is consolidated because of the media coverage of the local success stories or good practice examples. The bridging social capital is consolidated through workshops and international conferences, but also due to foreign investors' involvement.

Much work still needs to be done to identify the necessary measures supporting renewable energy practices and implementation of related policies in Romania, especially concerning citizens' perceptions, attitudes, and behaviour, all this directly impacting the development at various spatial scales.

Besides, not having elements of comparison from previous studies, analysing the dynamics of the framing practices on renewable energy did not offer us a full insight in how to accelerate the integration of renewable energy and the move towards a sustainable energy system. According to Buunk "all of these actors have a different background and different interest which influences their view on the need for the integration of renewables and the way of integrating. The complexity of the issue and the large heterogeneity of the actors involved makes the integration of renewables a very complicated process" $(2016$, p. 3). Further research should consider more qualitative methods for an in-depth study on the Romanians' attitudes towards renewable energy use (e.g. interviews, focus groups).

Further research should also aim at answering to what extent the social capital influences the Romanians on the practices regarding the use of renewable energies and to investigate the role of social capital in increasing awareness about using renewable energy. It should assess the role of social capital in implementing policies and practices for using renewable energy and it should answer the following questions: Is there a common plan of action of public authorities and citizens? Is there any direct involvement of the society members in policies? Are the public institutions and the local communities cooperating in the field of renewable energy? What measures should be considered to increase the confidence level within the relation between the public institutions and the civil society in the field of renewable ene rgy? Does all this result in an increase of the measures that involve the population in the decisionmaking process (public debates, participatory budgeting projects - taking over projects from organizations or citizens, focus groups, joint working groups, suggestion boxes, open hours, deliberative forums, discussion cell planning, tripartite commissions and workshops)?

The results of this study contribute to research on the Romanian territorial identity and pave the way for researching its possible impact on renewable energy policy and practices. It could be useful for public policies concerning the development of renewable energy, where the human factor is a key actor, whose knowledge and awareness levels should be raised, besides making the sector more economically efficient and environmentally friendly. 


\section{REFERENCES}

AGENTIA LOCALĂ A ENERGIEI ALBA [LOCAL AGENCY OF ENEERGY ALBA] (2009). Workshop „Dezvoltarea unui proiect de energie eoliană în judeţul Alba" [Workshop on "The Development of a Project on Wind Energy in Alba County"]. Retrieved 5 June 2019, from https://alea.ro/portofoliu/actuni-alea/workshop-dezvoltarea-unuiproiect-de-energie-regenerabila-in-judetul-alba

AGENTIA LOCALĂ A ENERGIEI ALBA [LOCAL AGENCY OF ENEERGY ALBA] (2014). Workshop „Energia regenera bilă și mediul rural" [Workshop on "Renewable Energy in the Rural Area"]. Retrieved 5 June 2019, from https://alea.ro/publicatii/stiri/workshop-energia-regenerabila-si-mediul-rural

AGENTIA PENTRU DEZVOLTARE REGIONALĂ CENTRU [AGENCY FOR REGIONAL DEVELOPMENT. CENTRE] (2010). Workshop "Cercetare şi inovare în sisteme de energie regenerabilă" [Workshop on "Research and Innovation in Renewable Energy Systems"]. Retrieved 10 May 2019, from http://www.adrcentru.ro/proiecte-regionale/workshop-cercetare-si-inovare-in-sisteme-de-energieregenerabila/

ALEXIU, T.M., LAZĂR, T.A., \& BACIU, E.L. (2011). Community Participation and Involvement in Social Actions. Transylvanian Review of Administrative Sciences, 33E, 5-22.

ARNSTEIN, S.R. (1969). A Ladder of Citizen Participation. Journal of American Planning Association, 35(4), 216-224.

BÄR, H., JACOB, K., \& WERLAND, S. (2011). Green Economy Discourses in the Run-Up to Rio 2012. Berlin: Freie Universität Berlin, Environmental Policy Research Centre.

BENEDEK, J., SEBESTYÉN, T.-T., \& BARTÓK, B. (2018). Evaluation of Renewable Energy Sources in Peripheral Areas and Renewable Energy-Based Rural Development. Renewable and Sustainable Energy Reviews, 90, 516-535.

BHANDARI, H. \& YASUNOBU, K. (2009). What Is Social Capital? A Comprehensive Review of the Concept. Asian Journal of Social Science, 37(3), 480-510.

BOAS, I. \& ROTHE, D. (2016). From Conflict to Resilience? Explaining Recent Changes in Climate Security Discourse and Practice. Environmental Politics, 25(4), 613-632, DOI: 10.1080/09644016.2016.1160479

BUNDǍ, R.N. (2005/2006). Social Capital and Economic Development - A New Direction in Institutional Research. Analele Știinţifice ale Universităţii „,Alexandru loan Cuza” din Iaşi, LII/LIII Ştiinţe Economice, 230-235.

BUUNK, J. (2016). Understanding the Dynamics of the Renewable Energy Discourse: The Framing Practices of Heterogeneous Actors. Master Thesis, Utrecht University Repository. Retrieved 20 May 2019, from https://dspace.library.uu.nl/handle/1874/328541

CEBOTARI, S. \& BENEDEK, J. (2017). Renewable Energy Project as a Source of Innovation in Rural Communities: Lessons from the Periphery. Sustainability, 9, 509. doi:10.3390/su9040509

CEBOTARI, S. (2017). Renewable Energy Projects and the Dynamics of Peripheralization in North-West Romania. Ph.D. Thesis, Faculty of Geography, Babeş-Bolyai University, Cluj-Napoca, Romania.

CIRSTEA, D.Ş., MARTIȘ, C.S., CIRSTEA, A., CONSTANTINESCU-DOBRA, A., \& FULOP, M.T. (2018). Current Situation and Future Perspectives of the Romanian Renewable Energy. Energies, 11(12), art. no. 3289.

CLARIDGE, T. (2004). Social Capital and Natural Resource Management. An Important Role for Social Capital? M.Sc. Thesis. School of Natural and Rural Systems Management, University of Queensland, Brisbane. Retrieved 15 March 2019, from https://www.socialcapitalresearch.com/wp-content/uploads/2013/01/Social-Capitaland-NRM.pdf

COFFEY, B. (2016). Unpacking the Politics of Natural Capital and Economic Metaphors in Environmental Policy Discourse. Environmental Politics, 25(2), 203-222, DOI: 10.1080/09644016.2015.1090370

COUNCIL OF EUROPE CONFERENCE OF MINISTERS RESPONSIBLE FOR SPATIAL/REGIONAL PLANNING (CEMAT) (2000). Guiding Principles for Sustainable Spatial Development of the European Continent. Adopted at the $12^{\text {th }}$ Session of the European Conference of Ministers Responsible for Regional Planning on 7-8 September 2000, in Hanover. Retrieved 7 April 2019, from https://rm.coe.int/1680700173

DIAZ ALONSO, F. (2018). Renewable Energy in the EU. Share of Renewables in Energy Consumption in the EU Reached $17 \%$ in 2016. Eleven Member States Already Achieved Their 2020 Targets. EUROSTAT News 
Release. Retrieved 28 April 2019, from https://ec.europa.eu/eurostat/documents/2995521/8612324/825012018-AP-EN.pdf/9d28caef-1961-4dd1-a901-af18f121fb2d

DRĂGAN, A. \& POPA, N. (2017). Social Economy in Post-communist Romania: What Kind of Volunteering for What Type of NGOs? Journal of Balkan and Near Eastern Studies, 19(3), 330-350.

DRID, T. (2010). Discourse Analysis: Key Concepts and Perspectives. Retrieved 6 April 2019, from https://www.researchgate.net/publication/282184078_DISCOURSE_ANALYSIS_KEY_CONCEPTS_AND_PERSPECTIVES

EUROPEAN COMMISSION (2018). Eurostat Statistics Explained. Retrieved 28 April 2019, from https://ec.europa.eu/eurostat/statistics-explained/index.php?title=File:Figure_1-

Share_of_energy_from_renewable_sources_2004-2016.png

EUROPEAN COMMISSION (2019). Eurostat. Your Key to European Statistics. Retrieved 28 April 2019, from https://ec.europa.eu/eurostat/web/products-eurostat-news/-/DDN-20190222-1

EUROPEAN COMMISSION, DIRECTORATE-GENERAL FOR RESEARCH AND INNOVATION (2018). Progress in Accelerating Clean Energy Innovation. Luxembourg: Publications Office of the European Union. Retrieved 10 April 2019, from https://ec.europa.eu/research/energy/pdf/accelerating_clean_energy_innovation_progress_report.pdf

EUROPEAN ENERgy ReSEARCH ALLIANCE (EERA) (2019). Our Joint Programmes. Retrieved 18 April 2019, from https://www.eera-set.eu/eera-joint-programmes-jps/list-of-jps/

FERGUSON, P. (2015). The Green Economy Agenda: Business as Usual or Transformational Discourse? Environmental Politics, 24(1), 17-37, DOI: 10.1080/09644016.2014.919748

FUKUYAMA, F. (2010). Social Capital, Civil Society and Development. Third World Quarterly, 22(1), 7-20.

HARUTA, C. \& RADU, B. (2010). Citizen Participation in the Decision-Making Process at Local and County Levels in the Romanian Public Institutions. Transylvanian Review of Administrative Sciences, 31E, 76-92.

HAVADI-NAGY, K.X., ILOVAN, O.-R., DAMYANOVIC, D., REINWALD, F., \& MĂRGINEAN, M. (2017). Advocacy for Participatory Rural Development. A Comparison of Two Case Studies from Romania and Austria. In P. Jordan (ed.), New Developments in the Rural Space of Central and South-East Europe. Proceedings of the meeting of the Working Group on Central Europe in conjunction with the German Congress of Geography, Berlin, September 30, 2015. HEFT 43 (pp. 121-150). Wien: Verlag der Österreichischen Akademie der Wissenschaften. DOI: 10.1553/IS R_FB043

HIRSCHMAN, A.O. (1984). Against Parsimony: Three Easy Ways of Complicating Some Categories of Economic Discourse. The American Economic Review, 74(2). Papers and Proceedings of the Ninety-Sixth Annual Meeting of the American Economic Association, 89-96. Retrieved 18 April 2019, from http://regulationbodyofknowledge.org/wpcontent/uploads/2013/03/Hirschman_Against_Parsimony_Three.pdf

HUYBRECHTS, B. \& MERTENS, S. (2014). The Relevance of the Cooperative Model in the Field of Renewable Energy. Annals of Public and Cooperative Economics, 85, 193-212.

JACOBS, K. (2006). Discourse Analysis and its Utility for Urban Policy Research. Urban Policy and Research, 24(1), 3952. DOI: $10.1080 / 08111140600590817$

LEQUEUX-DINCĂ, A.-I. \& DINCĂ, N. (2017). Energiile regenerabile - domeniu prioritar al tranziţiei energetice durabile a Uniunii Europene [Renewable Energies - Priority Field for the Sustainable Energy Transition of the European Union]. Terra, XLVIII(1-2), 203-209. Retrieved 10 June 2019, from http://www.cdpress.ro/pageflip/TERRA_SGR_2017/index.html\#p=205

MANOLE, A.M. (2012). Coeziunea socială - o analiză post-criză [Social Cohesion - A Post-crisis Analysis]. Economie Teoretică şi Aplicată, XIX(11), 111-118. Retrieved 10 May 2019, from http://store.ectap.ro/articole/801_ro.pdf

MARTIKKE, S. (2017). Social Capital - an Overview, Greater Manchester Center for Voluntary Organisation. Retrieved 17 April 2019, from https://www.gmcvo.org.uk/system/files/social_capital_an_overview_0.pdf

MARUSYK, Y. (2019). Securing A Spot Under the Sun? Gas and Renewables in the EU-Russian Energy Transition Discourse. East European Politics, 35(2), 182-200. DOI: 10.1080/21599165.2019.1612371

MATTISSEK, A. (2010). Analyzing City Images. Potentials of the "French School of Discourse Analysis". Erdkunde, 64(4), 315-326. 
MINISTERUL ENERGIEI [MINISTRY OF ENERGY] (2017). Planul Național de Acțiune în Domeniul Eficienței Energetice IV [National Plan for Action in the Field of Energetic Efficiency IV]. Retrieved 12 May 2019, from https://www.juridice.ro/wp-content/uploads/2018/02/Proiectul-3.pdf

MINISTERUL ENERGIEI [MINISTRY OF ENERGY] (2018). Strategia energetică a României 2019-2030, cu perspectiva anului 2050 [Energy Strategy of Romania 2019-2030, with the Perspective of the Year 2050]. Retrieved 12 May 2019, from http://energie.gov.ro/transparenta-decizionala/strategia-energetica-a-romaniei-20192030-cu-perspectiva-anului-2050/

MÜLLER, A. (2014). The Theory of Social Capital in a Supply Management Context. $3^{\text {rd }}$ IBA Bachelor Thesis Conference, July 3rd, 2014, Enschede, The Netherlands, 1-13. Retrieved 20 March 2019, from https://essay.utwente.nl/65252/1/M\%C3\%BCller_BA_MB.pdf

NEGUT, A. (2013). Economie socială, capital social şi dezvoltare locală [Social Economy, Social Capital and Local Development]. Calitatea Vieții, XXIV(2), 195-212. Retrieved 10 May 2019, from https://www.revistacalitateavietii.ro/2013/CV-2-2013/06.pdf

NISTOR, L., TîRHAŞ, C., \& ILUT, P. (2011). Linkages between Informal and Formal Social Capital and Their Relations with Forms of Trust. A Focus on Romania. Transylvanian Review of Administrative Sciences, 34E, 155-174.

PARLAMENTUL ROMÂNIEI, CAMERA DEPUTATILOR [PARLIAMENT OF ROMANIA, CHAMBER OF REPRESENTATIVES] (2010). Legea nr. 220/2008 pentru stabilirea sistemului de promovare a producerii energiei din surse regenerabile de energie [Law no. 220/2008 for Establishing the Promotion System for Energy Production from Renewable Energy Sources]. Republished in Monitorul Oficial al României, partea l, nr. 577/13.VIII.2010

PEIZERAT, C. (1997). An Interpretation of Europe in Planning and Property Development Based on Discourse Analysis: The Example of Business Sites. International Planning Studies, 2(1), 27-44, DOI: $10.1080 / 13563479708721667$

PETERSEN, L.K. (2007). Changing Public Discourse on the Environment: Danish Media Coverage of the Rio and Johannesburg UN Summits. Environmental Politics, 16(2), 206-230, DOI: 10.1080/09644010701211676

POPA, A.R. \& DULAMĂ, M.E. (2017). Chapter 13. Discourse Analysis. In Ilovan, O.-R., Doroftei, I. (eds.), Qualitative Research in Regional Geography. A Methodological Approach (pp. 231-248). Cluj-Napoca: Presa Universita ră Clujeană.

PUTNAM, R.D. (1993). Making Democracy Work: Civic Traditions in Modern Italy. Princeton: Princeton University Press.

PUTNAM, R.D. (2002). Democracies in Flux: The Evolution of Social Capital in Contemporary Society. Oxford: Oxford University Press.

RAM, M., AGHAHOSSEINI, A., \& BREYER, C. (2019). Job Creation During the Global Energy Transition Towards $100 \%$ Renewable Power System by 2050. Technological Forecasting and Social Change, Available online 9 July 2019, https://doi.org/10.1016/j.techfore.2019.06.008

SOAITA, A.M. \& WIND, B. (2020). Urban Narratives on the Changing Nature of Social Capital in Post-Communist Romania. Europe-Asia Studies, 72(4), 712-738. DOI: 10.1080/09668136.2020.1718064

ŠTURC, M. (2016). Renewable Energy in the EU. Share of Renewables in Energy Consumption in the EU Rose Further to $16 \%$ in 2014. Nine Member States Already Achieved Their 2020 Targets. EUROSTAT Newsletter. Retrieved 25 October 2019, from http://ec.europa.eu/eurostat/documents/2995521/7155577/8-10022016-APEN.pdf/38bf822f-8adf-4e54-b9c6-87b342ead339

THE EUROPEAN PARLIAMENT AND THE COUNCIL OF THE EUROPEAN UNION (2018). Directive (EU) 2018/2001 of the European Parliament and of the Council of 11 December 2018 on the Promotion of the Use of Energy from Renewable Sources. Official Journal of the European Union. Retrieved 28 April 2019, from https://eurlex.europa.eu/legal-content/EN/TXT/PDF/?uri=CELEX:32018L2001\&from=EN

THE EUROPEAN PARLIAMENT AND THE COUNCIL OF THE EUROPEAN UNION (2009). Directive 2009/28/EC of the European Parliament and of the Council of 23 April 2009 on the Promotion of the Use of Energy from Renewable Sources and Amending and Subsequently Repealing Directives 2001/77/EC and 2003/30/EC Official Journal of the European Union. Retrieved 28 April 2019, from https://eur-lex.europa.eu/legalcontent/EN/TXT/PDF/?uri=CELEX:32009L0028\&from=ro

TIRMIZI, S.N.A. (2005). The Contribution of Levels of Social Capital to Community Development. Ph.D. Thesis. Digital Repository @ lowa State University. https://doi.org/10.31274/rtd-180813-140 
VOICU, B. (2008). Capitalul social ca premisă a dezvoltării durabile [Social Capital as Premise for Sustainable Development]. Calitatea Vieții, XIX(1-2), 85-105. Retrieved 20 May 2019, from https://www.revistacalitateavietii.ro/2008/CV-1-2-2008/05.pdf

WOLLEBAEK, D. \& SELLE, P. (2002). Does Participation in Voluntary Associations Contribute to Social Capital? The Impact of Intensity, Scope, and Type. Nonprofit and Voluntary Sector Quarterly, 31(1), 32-61, https://doi.org/10.1177/0899764002311002

\section{Comments to the online resources on the following links}

https://www.facebook.com/energiaviitorului/posts/1616366208422771 (Retrieved 15 March 2019)

https://www.facebook.com/energiaviitorului/posts/1554311184628274 (Retrieved 15 March 2019)

https://www.facebook.com/enerqiaviitorului/posts/162265714446034 (Retrieved 15 March 2019)

https://www.youtube.com/watch?v=LpDf4R 4Vwo (Retrieved 14 March 2019)

http://www.ziare.com/mediu/energie-regenerabila/remus-borza-avertizeaza-sute-de-proiecte-din-energiaregenerabila-vor-esua-125466 (Retrieved 12 March 2019)

http://www.ziare.com/mediu/energie-regenerabila/investitille-in-energia-regenerabila-din-romania-se-fac-cu-taxape-prietenie-1034989\#comentarii (Retrieved 13 March 2019)

https://www.facebook.com/energiaviitorului/posts/1563559287036797 (Retrieved 15 March 2019)

https://forum.softpedia.com/topic/688941-investitii-verzi-pe-teritoriul-romaniei/(Retrieved 12 March 2019)

https://www.youtube.com/watch?v=f-e g6b1GaA (Retrieved 12 March 2019)

https://www.facebook.com/energiaviitorului/posts/1546368625422530 (Retrieved 15 March 2019)

http://www.ziare.com/economie/stiri-economice/lectia-germana-a-energiei-regenerabile-983254\#comentarii (Retrieved 13 March 2019)

https://www.youtube.com/watch?v=c5itDZ-MFZc (Retrieved 12 March 2019)

http://riscograma.ro/7532/cat-de-rentabila-este-mica-productie-de-energie-electrica/(Retrieved 12 March 2019)

http://www.ziare.com/mediu/energie-regenerabila/investitille-in-energia-regenerabila-din-romania-se-fac-cu-taxape-prietenie-1034989\#comentarii (Retrieved 12 March 2019)

http://www.ziare.com/economie/stiri-economice/lectia-germana-a-energiei-regenerabile-983254\#comentarii

(Retrieved 12 March 2019) 